\title{
Abnormal Properties of Collagen Lysyl Hydroxylase from Skin Fibroblasts of Siblings with Hydroxylysine-Deficient Collagen
}

\author{
Ruth S. Quinn and Stephen M. Krane \\ From the Department of Medicine, Harvard Medical School, and Medical \\ Services (Arthritis Unit), Massachusetts General Hospital, \\ Boston, Massachusetts 02114
}

\begin{abstract}
A в S T R A C T Skin fibroblasts from two siblings with hydroxylysine-deficient collagen (Ehlers-Danlos syndrome, type VI) contained normal levels of collagen prolyl hydroxylase activity but were markedly deficient in collagen lysyl hydroxylase activity. The deficiency was evident in all fractions of cell lysates, in low and high ionic strength buffers, and in detergent. Assays of mixtures of wild-type and mutant cell lysates indicated no activation of mutant enzyme by factors in wild-type cells or inhibition of normal enzyme by material in mutant cells. Wild type or mutant cells cultured with ascorbic acid $(50 \mu \mathrm{g} / \mathrm{ml}$ of culture medium, added daily) contained approximately the same level of lysyl hydroxylase activity as cells cultured without ascorbate, but prolyl hydroxylase activity without ascorbate was depressed in both an average of $41 \%$. The mutant lysyl hydroxylase was less stable at $37^{\circ} \mathrm{C}$ than the wild type and did not form high molecular weight aggregates in low ionic strength buffers, as did the control enzyme. The activity of the mutant enzyme was maximally stimulated after dialysis against buffer solutions containing $10 \mathrm{mM}$ dithiothreitol. When assayed in $100 \mu \mathrm{M}$ dithiothreitol, the mutant enzyme exhibited a higher apparent $K_{m}$ for ascorbate $(20 \mu \mathrm{M})$ than the wild type $(4 \mu \mathrm{M})$. In $1.0 \mathrm{mM}$ dithiothreitol the mutant enzyme's apparent $K_{m}$ for ascorbate was reduced to $5 \mu \mathrm{M}$. Wild type and mutant enzymes had the same apparent $K_{m}$ for $\alpha$-ketoglutarate $(20 \mu \mathrm{M})$. The properties of prolyl hydroxylase in wild type and mutant cells were identical: apparent $K_{m}$ 's for ascorbate and $\alpha$-ketoglutarate were $100 \mu \mathrm{M}$ and $20 \mu \mathrm{M}$, respectively. If mutant enzyme protein with altered kinetic properties is the only enzyme functioning to hydroxylate lysyl residues in collagen, the variations in hydroxylysine content observed in collagen from different tissues in the subjects reported here could be in
\end{abstract}

Received for publication 30 June 1975 and in revised form 25 August 1975.

part due to differences in cofactor concentrations and in rate and sequence of events in collagen synthesis in different tissues.

\section{INTRODUCTION}

Current knowledge of the events in collagen metabolism is such that the biochemical basis of certain connective tissue disorders can now be explained. Human hydroxylysine-deficient collagen disease (Ehlers-Danlos syndrome, type VI) is a disorder characterized by a specific aberration in collagen synthesis. This heritable disease was first identified in two sisters with features suggestive of both Ehlers-Danlos and Marfan syndromes (1). The clinical manifestations of the disease included kyphoscoliosis, joint laxity with recurrent joint dislocations, hyperextensible skin, and slow wound healing. Amino acid analysis of the dermis from the two children showed that the skin collagen contained a normal amount of hydroxyproline, but the hydroxylysine content was markedly reduced to approximately $5 \%$ of normal. The hydroxylysine content of other tissues was reduced to a variable extent; fascia contained 14-28\%, bone about $43 \%$, and cartilage $90 \%$ of the amount present in corresponding tissues from normal subjects. The skin collagen from these patients was abnormally soluble in denaturing solvents such as $4 \mathrm{M} \mathrm{CaCl}_{2}$ and $9 \mathrm{M} \mathrm{KSCN}$. These observations were consistent with a deficiency of hydroxylysine-derived intermolecular cross-links, and analysis of borohydride-reducible cross-links indicated abnormalities in the nature, distribution, and amount of these moieties in the dermal collagen (2).

Hydroxyproline and hydroxylysine are formed by enzymatic oxidation of prolyl and lysyl residues in precursor component chains of the collagen molecule. The hydroxylations are catalyzed by two separate enzymes, prolyl hydroxylase, (prolyl-protocollagen hydroxylase 
or collagen prolyl hydroxylase EC 1.14.11.2), and lysyl hydroxylase (lysyl-protocollagen hydroxylase or collagen lysyl hydroxylase). Lysates of cultured skin fibroblasts from the affected siblings contained normal levels of prolyl hydroxylase activity but reduced lysyl hydroxylase activity (less than $15 \%$ of that present in fibroblasts from normal subjects) (3). In vitro assays of prolyl and lysyl hydroxylase activity in crude lysates of normal and mutant cells require the presence of oxygen, $\alpha$-ketoglutarate, ascorbic acid, and ferrous ion for the hydroxylation reactions to occur at optimal rates. Thus the enzymes in human skin fibroblasts have characteristics in common with prolyl hydroxylases from human and rat liver $(4,5)$, newborn rat skin (6), chick embryos (7), and mouse L-929 fibroblasts $(8,9)$, as well as lysyl hydroxylases from chick embryo $(10,11)$ and fetal rat skin (12).

Further studies of collagen hydroxylases in skin fibroblasts were performed to learn more about human enzymes from this source. Comparison of the properties of hydroxylases from normal and deficient cells might thus help to elucidate the cause of defective collagen lysyl hydroxylation. This communication reports studies of characteristics of collagen lysyl and prolyl hydroxylases in normal cells and in cells from two siblings with hydroxylysine-deficient collagen (3). The lysyl hydroxylase from deficient cells has chemical, physical, and kinetic properties significantly different from the enzyme in normal cells.

\section{METHODS}

Fibroblast lysates. Cells were grown in 100-mm diameter plastic petri dishes (Falcon Plastics, Division of BioQuest, Oxnard, Calif.) or in glass roller bottles, the latter with an approximate growth surface area of $600 \mathrm{~cm}^{2}$. Mutant 1 and 2 refer to cells grown from patients 1 and 2, respectively, with Ehlers-Danlos syndrome type VI $(1,3)$. Most cultures were in passage 10-20. Control cells used in earlier studies were from normal subjects age-matched for the mutant subjects. Some of these cells were no longer available during the present studies. All control cells used in the present experiments were from children aged 3 wk-18 yr and matched approximately for passage number and growth rate. The culture medium, modified Eagle's medium (Grand Island Biological Co., Grand Island, N. Y.) supplemented with $15 \%$ fetal calf serum, glutamine, essential and nonessential amino acids, glucose $(1.5 \mathrm{mg} / \mathrm{ml})$, sodium pyruvate $(0.22$ $\mathrm{mg} / \mathrm{ml})$, and $\mathrm{Fe}\left(\mathrm{NO}_{3}\right)_{3} .9 \mathrm{H}_{2} \mathrm{O}(1 \mathrm{mg} / \mathrm{ml})$ was changed twice weekly. Cultures 2 days after confluence were harvested by trypsinization, cells were counted in a hemocytometer, separated from the medium by centrifugation at $1,200 \mathrm{~g}$ for $10 \mathrm{~min}$, washed three times with phosphatebuffered saline, and then suspended at a density of $0.1-1$ $\times 10^{8}$ cells $/ \mathrm{ml}$ in $40 \mathrm{mM}$ Tris- $\mathrm{HCl}(\mathrm{pH} \mathrm{7.4),250 \textrm {mM }}$ sucrose, and $50 \mathrm{mM} 2$-mercaptoethanol (2-ME). ${ }^{1}$ All operations after trypsinization were done at $4^{\circ} \mathrm{C}$. The cell sus-

${ }^{1}$ Abbreviations used in this paper: DTT, dithiothreitol; 2-ME, 2-mercaptoethanol; PCMB, para-chloromercuribenzoate. pension was lysed by sonication for $2 \mathrm{~min}$ in a Raytheon model DF 101 sonic oscillator (Raytheon Co., Sorensen Operation, Production Equipment Dept., Norwalk, Conn.). The lysate was centrifuged at $50,000 \mathrm{~g}$ for $60 \mathrm{~min}$, and the supernate was carefully separated from the overlying lipid layer. In some experiments acetone powders were prepared according to the method of Morton (13).

Protocollagen substrate. The method of preparation of $\left[3,4-{ }^{3} \mathrm{H}\right]$ proline or $\left[\mathrm{G}-{ }^{3} \mathrm{H}\right]$ lysine (New England Nuclear, Boston, Mass.) protocollagen substrate from chick embryo tibia $(4,11)$ as modified by Krane et al. (3) was used. Although the same method of substrate preparation was always followed, for unexplained reasons different substrate preparations exhibited variable activities with the same enzyme preparation.

With constant amounts of control human fibroblast lysate and incubation times of $60-120 \mathrm{~min}$, a plateau in hydroxylysine formed was not reached with amounts of underhydroxylated collagen substrates tested up to 10 times those used in most assays reported here. Because of the amounts of radioactivity necessary and the relatively low yields of underhydroxylated substrate, it was not practical to determine saturating conditions for every substrate preparation or to attempt to employ saturating collagen substrate conditions in every assay.

Enzyme assays. Assays for lysyl or prolyl hydroxylase contained (in a total volume of $1.0 \mathrm{ml}$ ) $25 \mathrm{mM}$ Tris- $\mathrm{HCl}$ (pH 7.2), $100 \mu \mathrm{M} \alpha$-ketoglutarate (Sigma Chemical Co., Inc., St. Louis, Mo.), $100 \mu \mathrm{M}$ ferrous sulfate, $500 \mu \mathrm{M}$ ascorbic acid (recrystallized, Fisher Scientific Co., Pittsburgh, Penn.), $0.5 \mathrm{mg}$ catalase (Sigma), $100 \mu \mathrm{M}$ dithiothreitol (DTT) (Calbiochem, San Diego, Calif.), $2 \mathrm{mg}$ of bovine serum albumin (Miles Laboratories, Inc., Elkhart, Ind.) cell lysate (usually 10-25 $\mu 1$ of lysates from sonicated cells suspended at $0.1-1 \times 10^{8}$ cells $/ \mathrm{ml}$ ) and $0.5-2.5 \times 10^{5}$ $\mathrm{dpm}$ of protocollagen substrate. The enzyme reactions were initiated by addition of either substrate or enzyme and, unless otherwise indicated, assay mixtures were incubated for $60-120 \mathrm{~min}$ in air at $37^{\circ} \mathrm{C}$. Prolyl hydroxylase assays were terminated by the addition of $0.5 \mathrm{ml}$ of $15 \%$ trichloroacetic acid. Tritiated water produced on hydroxylation of labeled proline was separated from the reaction mixture by vacuum distillation. Portions of the distillate were counted in $10 \mathrm{ml}$ of Insta-gel (Packard Instrument Co., Inc., Downers Grove, Ill.) containing $3 \mathrm{ml}$ of $\mathrm{H}_{2} \mathrm{O}$ with an efficiency of approximately $30 \%$. Lysyl hydroxylase assays were terminated by addition of $10 \mathrm{ml}$ of cold $\left(-20^{\circ} \mathrm{C}\right)$ acetone. The labeled formaldehyde produced by periodate oxidation of carbon 6 of [G- ${ }^{3} \mathrm{H}$ ]hydroxylysine was coupled with dimedone, and the complex was extracted into 15-20 $\mathrm{ml}$ of toluene $(3,14) .10 \mathrm{ml}$ of the toluene phase was added to a scintillation counting vial containing $2 \mathrm{ml}$ of $1.5 \% 2,5$ diphenyloxazole and $0.005 \%$ p-bis [2-(5-phenyloxazolyl)]benzene in toluene. Radioactivity was assayed with a Packard model 3375 Tricarb scintillation spectrometer.

Lysyl hydroxylase activities were usually expressed as disintegrations per minute of $\left[{ }^{3} \mathrm{H}\right]$ formaldehyde produced per $10^{8}$ cells per hour, and prolyl hydroxylase activities were expressed as distintegrations per minute $\left[{ }^{3} \mathrm{H}\right]$ water formed per $10^{8}$ cells per hour. The absolute values of enzyme activities can only be compared when identical substrate preparations are used. In any one experiment, the same substrate preparation (prolyl or lysyl) was utilized in all assays. Lactate dehydrogenase activity was measured by the method of Klevecz and Ruddle (15).

Measurements of apparent $K_{m}$ for cosubstrates. Under standard assay conditions, the rate of formation of $\left[{ }^{8} \mathrm{H}\right]-$ 
hydroxylysine by enzymes in wild-type and mutant cells was linear for at least $60 \mathrm{~min}$. Apparent $K_{m}$ values were measured by incubation for $30-40 \mathrm{~min}$ with variation of the concentration of one substrate.

Ascorbate concentrations. Ascorbate concentrations were determined by modified spectrophotometric methods utilizing diazotized 4 methoxy-2-nitroaniline $(16,17)$. Standard ascorbate solutions of $5-50 \mu \mathrm{g} / \mathrm{ml}$ (in $25 \mathrm{mM}$ Tris- $\mathrm{HCl}, \mathrm{pH}$ 7.2) were prepared by dilution of a stock solution containing $500 \mu \mathrm{g} / \mathrm{ml}$. Color reagent was prepared by dissolving $500 \mathrm{mg}$ of 4-methoxy-2-nitroaniline in glacial acetic acid $(125 \mathrm{ml}$ ) and diluting the solution to $250 \mathrm{ml}$ with $10 \%$ aqueous sulfuric acid. The color reagent $(2 \mathrm{ml})$ was diazotized by reaction with $2 \mathrm{ml}$ of fresh $0.2 \%$ sodium nitrite solution, and $75 \mathrm{ml}$ of absolute ethanol was added as soon as the reaction mixture became colorless. Then $1.0 \mathrm{ml}$ of diazotized color reagent solution was immediately added to $1.0 \mathrm{ml}$ of ascorbate solutions and mixed for $1 \mathrm{~min}$, and $0.5 \mathrm{ml}$ of $10 \%$ sodium hydroxide was added. The blue product exhibited an absorption maximum at $570 \mathrm{~nm}$. A standard curve relating absorbance at $570 \mathrm{~nm}$ versus ascorbate concentration was linear in the range $5-100 \mu \mathrm{g} / \mathrm{ml}$. Ascorbate concentrations in freshly prepared solutions of dehydroascorbic acid (in $25 \mathrm{mM}$ Tris- $\mathrm{HCl}, \mathrm{pH} 7.2$ ) containing varying concentrations of DTT were established by comparison with the standard curve.

\section{RESULTS}

Collagen hydroxylase activities in normal and deficient cells

Whole cell lysates of mutant cells and $50,000 \mathrm{~g}$ supernates contained levels of prolyl hydroxylase activity within the range of that in control cells, but in both preparations the lysyl hydroxylase activity in mutant cells was markedly lower than that in any control cell (Table I). Because cells from different agematched normal subjects cultured under identical conditions contain variable levels of lysyl hydroxylase, prolyl hydroxylase, and lactate dehydrogenase activities, exact quantitation of a deficiency of lysyl hydroxylase activity can be arbitrary. In any given cell lysate, the ratio of the activity of collagen lysyl hydroxylase to that of collagen prolyl hydroxylase may best reflect relative lysyl hydroxylase activity, since both enzymes are presumed to be involved only in the biosynthesis of collagen.

Sonication of cell suspensions in buffer containing $0.1 \%$ Triton $\mathrm{X}-100$ did not significantly increase the collagen lysyl hydroxylase activity present in the 50,000 $g$ supernate of normal or mutant cell lysates. Suspensions of the $50,000 \mathrm{~g}$ pellets (in $40 \mathrm{mM}$ Tris- $\mathrm{HCl}, \mathrm{pH}$ 7.4, $250 \mathrm{mM}$ sucrose, and $50 \mathrm{mM} 2-\mathrm{ME}$ ) and extracts of acetone powders prepared from such suspensions contained residual lysyl and prolyl collagen hydroxylase activities, but all such preparations from mutant cells were deficient in lysyl hydroxylase activity. Though collagen lysyl hydroxylase from chick embryos has been found to be relatively insoluble in low ionic strength buffers (11), we found similar lysyl hydroxylase activity in $50,000 \mathrm{~g}$ supernates of fibroblast lysates in both high
TABLE I

Enzyme Activities in Human Skin Fibroblasts

\begin{tabular}{|c|c|c|c|c|c|}
\hline \multirow[b]{4}{*}{ Cells } & \multirow[b]{4}{*}{ Assayed } & \multicolumn{4}{|c|}{ Enzyme activities } \\
\hline & & \multirow{2}{*}{\multicolumn{2}{|c|}{$\begin{array}{cc}1 & 2 \\
\text { Hydroxylase }\end{array}$}} & \multirow{3}{*}{$\begin{array}{c}3 \\
\text { Lactate } \\
\text { dehydro- } \\
\text { genase }\end{array}$} & \multirow[t]{3}{*}{$1: 2$} \\
\hline & & & & & \\
\hline & & Lysyl & Prolyl & & \\
\hline & & \multicolumn{2}{|c|}{$\begin{array}{c}d p m \times 10^{-6} / 10^{8} \\
\text { cells } / h\end{array}$} & $\begin{array}{c}\mu m o l \\
N A D H \\
\text { oxidized / } \\
\min / 10^{8} \\
\text { cells }\end{array}$ & \\
\hline Mutant 1 & $\begin{array}{l}\text { Whole sonicate } \\
50,000 \text { g supernate }\end{array}$ & $\begin{array}{l}0.055 \\
0.033\end{array}$ & $\begin{array}{l}3.51 \\
3.03\end{array}$ & 59.9 & $\begin{array}{l}0.016 \\
0.011\end{array}$ \\
\hline Mutant 2 & $\begin{array}{l}\text { Whole sonicate } \\
50,000 \mathrm{~g} \text { supernate } \\
50,000 \mathrm{~g} \text { pellet } \\
\text { Acetone powder }\end{array}$ & $\begin{array}{l}0.319 \\
0.099 \\
0.014 \\
0.021\end{array}$ & $\begin{array}{l}5.92 \\
4.84 \\
0.397 \\
1.16\end{array}$ & 57.7 & $\begin{array}{l}0.054 \\
0.020 \\
0.036 \\
0.018\end{array}$ \\
\hline Control 1 & $\begin{array}{l}\text { Whole sonicate } \\
50,000 \mathrm{~g} \text { supernate } \\
50,000 \mathrm{~g} \text { pellet } \\
\text { Acetone powder }\end{array}$ & $\begin{array}{l}3.14 \\
2.26 \\
0.212 \\
0.645\end{array}$ & $\begin{array}{l}3.16 \\
2.70 \\
0.297 \\
1.42\end{array}$ & 26.3 & $\begin{array}{l}0.995 \\
0.838 \\
0.714 \\
0.454\end{array}$ \\
\hline Control 2 & $\begin{array}{l}\text { Whole sonicate } \\
50,000 \mathrm{~g} \text { supernate }\end{array}$ & $\begin{array}{l}3.08 \\
2.25\end{array}$ & $\begin{array}{l}6.97 \\
5.51\end{array}$ & 54.8 & $\begin{array}{l}0.441 \\
0.449\end{array}$ \\
\hline Control 3 & $\begin{array}{l}\text { Whole sonicate } \\
50,000 \mathrm{~g} \text { supernate }\end{array}$ & $\begin{array}{l}1.77 \\
1.69\end{array}$ & $\begin{array}{l}5.38 \\
3.81\end{array}$ & 37.5 & $\begin{array}{l}0.329 \\
0.444\end{array}$ \\
\hline Control 4 & $\begin{array}{l}\text { Whole sonicate } \\
50.000 \mathrm{~g} \text { supernate }\end{array}$ & $\begin{array}{l}1.34 \\
0.649\end{array}$ & $\begin{array}{l}4.57 \\
2.19\end{array}$ & 40.4 & $\begin{array}{l}0.293 \\
0.296\end{array}$ \\
\hline Control 5 & $\begin{array}{l}\text { Whole sonicate } \\
50.000 \mathrm{~g} \text { supernate } \\
50,000 \mathrm{~g} \text { pellet } \\
\text { Acetone powder }\end{array}$ & $\begin{array}{l}4.06 \\
2.42 \\
0.160 \\
0.298\end{array}$ & $\begin{array}{l}6.70 \\
7.32 \\
0.440 \\
1.002\end{array}$ & 56.8 & $\begin{array}{l}0.605 \\
0.330 \\
0.364 \\
0.297\end{array}$ \\
\hline
\end{tabular}

On day 1 , cultures were seeded concurrently at 20,000 cells $/ \mathrm{ml}(10 \mathrm{ml}$ medium) in $100-\mathrm{mm}$ diameter petri dishes. All cultures reached confluence simultaneously on day 6 except controls 2 and 5, which reached confluence on day 7. Cultures were harvested on day 7 , suspended in $40 \mathrm{mM}$ Tris- $\mathrm{HCl}$ (pH 7.4), $250 \mathrm{mM}$ sucrose, $50 \mathrm{mM}$ 2-ME, and lysed by sonication. Portions of the whole sonicates were reserved for assay and the remainders were centrifuged at $50,000 \mathrm{~g}$. The pellet thus obtained was suspended in the same volume of buffer in which the cells were originally lysed; portions of the suspensions were reserved for assay and acetone powders were prepared from the remainders.

and low ionic strength buffer $(20 \mathrm{mM}$ Tris- $\mathrm{HCl}$ buffer [pH 7.4], $200 \mathrm{mM} \mathrm{NaCl}, 100 \mathrm{mM}$ glycine, and $50 \mu \mathrm{M}$ DTT or $40 \mathrm{mM}$ Tris- $\mathrm{HCl}$ [pH 7.4], $250 \mathrm{mM}$ sucrose, and $50 \mathrm{mM} 2-\mathrm{ME}$ ). These studies also indicated that the presence of $50 \mathrm{mM} 2-\mathrm{ME}$ in the extracting buffer had no observable effect on either prolyl or lysyl hydroxylase activities.

There was no inhibition of the activity of lysyl hydroxylase from normal cells by proportionate amounts of mutant cell lysate, as shown in Fig. 1. To date we have not observed any change in the activities of collagen hydroxylases in control cells maintained in culture with repeated passages. However, we have recently found that certain cultured late-passage mutant cells contained a level of lysyl hydroxylase activity $25-35 \%$ of the activity in a given control cell (versus $2-15 \%$ in earlypassage cells), although the level of prolyl hydroxylase activity was unchanged. 


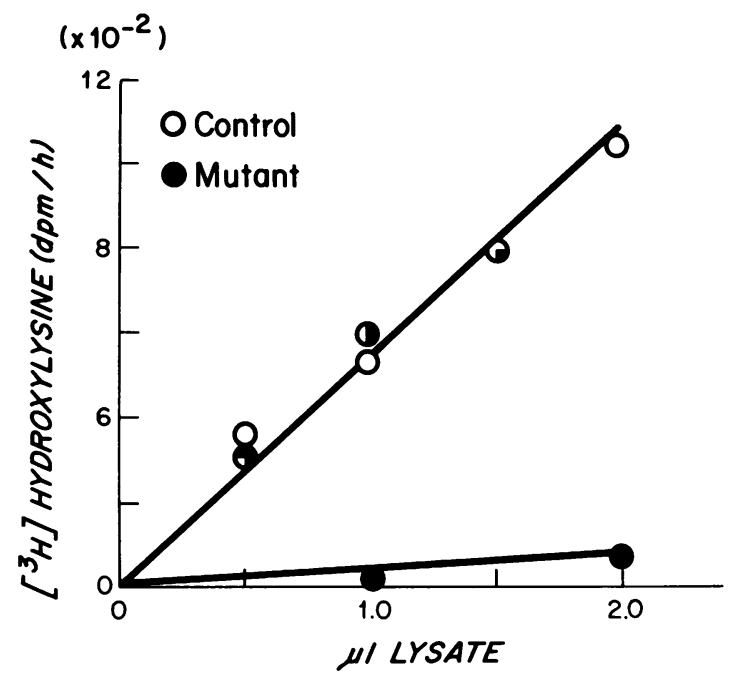

FIGURE 1 Lysyl hydroxylase activity in mixtures of wildtype and mutant fibroblast lysates. The $50,000 \mathrm{~g}$ supernates of normal or mutant cell lysates $\left(10^{8}\right.$ cells $\left./ \mathrm{ml}\right)$ were diluted 1: 19 with $40 \mathrm{mM}$ Tris- $\mathrm{HCl}$ ( $\mathrm{pH} \mathrm{7.4),} 250 \mathrm{mM}$ sucrose, $50 \mathrm{mM}$ 2-ME before assay. Mixtures assayed contained the amount of normal control lysate indicated by the abscissa plus a proportionate amount of mutant cell lysate indicated by the shaded area.

\section{Ascorbate and enzyme levels}

Lysyl hydroxylase activity in multiplying fibroblast cultures roughly paralleled the number of cells in the culture (Fig. 2A). At all time points examined after planting of the culture, the deficiency of lysyl hydroxylase activity in the mutant cells was evident. Daily supplementation of the culture medium with ascorbate (to $50 \mu \mathrm{g} / \mathrm{ml}$ ) produced no significant change (-15$+25 \%$ ) in lysyl hydroxylase activity in cultures of normal or mutant cells, although in one of three experiments the activity in mutant cells rose eightfold (but only to a level $12 \%$ of control).

Prolyl hydroxylase activity in wild type and mutant cells was affected adversely by the continuous presence of ascorbate in the culture medium. In three experiments (one of which is shown in Fig. 2B), at every time point studied, prolyl hydroxylase activity in cultures supplemented daily with ascorbate was less than the activity in unsupplemented cultures. At confluence, cultures of mutant and normal cells maintained in ascorbate contained from $19-61 \%$ (average $41 \%$ ) of the prolyl hydroxylase activity present in unsupplemented replicate cultures.

\section{Sulfhydryl compounds and enzyme activity}

Lysyl and prolyl hydroxylase activities were usually measured in assay mixtures containing $100 \mu \mathrm{M}$ DTT, as suggested by Rhoads and Udenfriend (6). We found that omission of DTT at this concentration had little effect on the rate of lysyl or prolyl hydroxylation by enzymes in cell lysates prepared and stored in buffer containing $50 \mathrm{mM}$ 2-ME; however, cell lysates dialyzed against buffers lacking 2-ME required DTT in the assay solution for significant rates of prolyl and lysyl hydroxylation (Table II). Para-chloromercuribenzoate (PCMB) inhibited both normal and mutant lysyl hydroxylases when preincubated with lysates in buffer lacking 2-ME but containing cofactors (ascorbate,
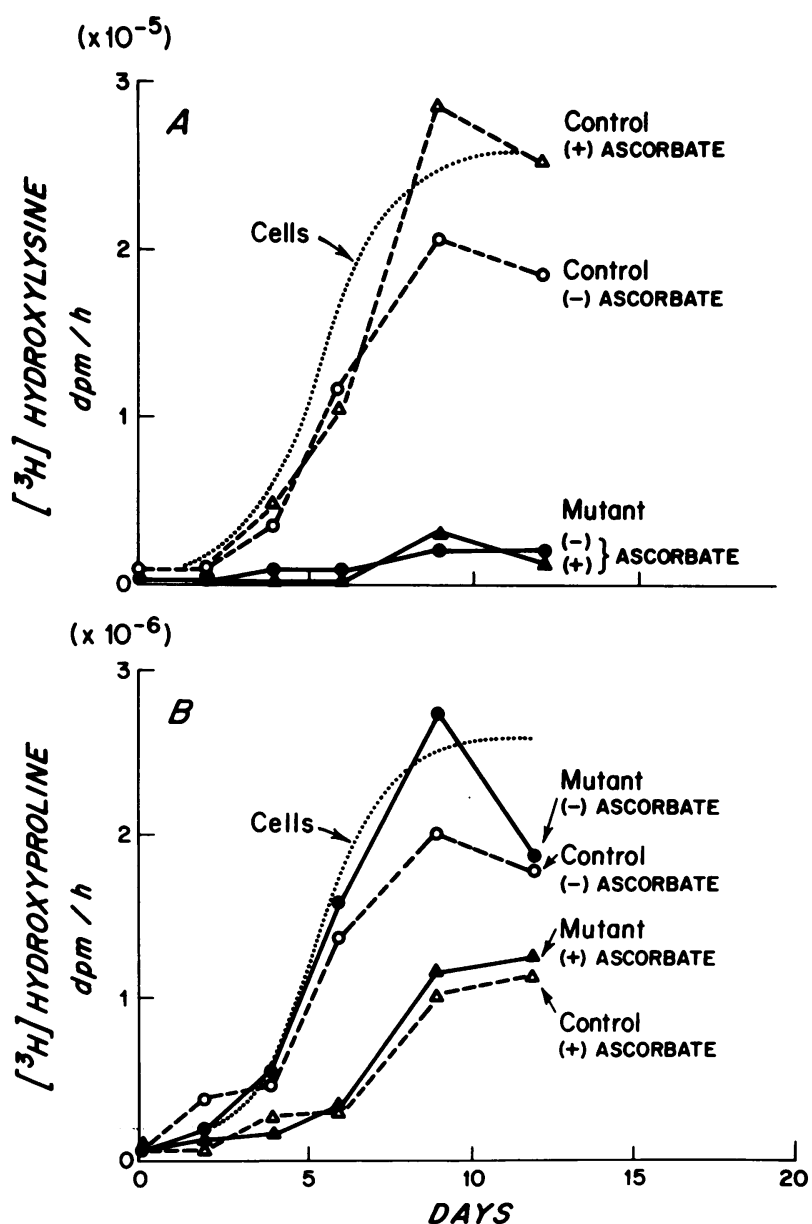

FIGURE 2 Collagen lysyl and prolyl hydroxylase activities in cell cultures grown with and without added ascorbate in the culture medium. On day 0 , replicate cultures were seeded with $2 \times 10^{5}$ cells in $100-\mathrm{mm}$ diameter plastic petri dishes (Falcon). Ascorbate (final concentration $50 \mu \mathrm{g} / \mathrm{ml}$ ) was added daily (from day 0 ) to one half of the cultures. Culture medium was changed twice weekly. (•) Enzyme activity in mutant cells cultured without ascorbate. (A) Activity in mutant cells cultured with ascorbate. (O) Activity in wild-type cells cultured without ascorbate. $(\Delta)$ Activity in wild-type cells cultured with ascorbate. $(\cdots)$ cells/five plates (at confluence approximately $25 \times 10^{6}$ cells) (For purposes of illustration the mean number of cells for all cultures is shown). 
TABLE II

Effect of Sulfhydryl Compounds and PCMB on Collagen Hydroxylase Activities

\begin{tabular}{cccccc}
\hline & & & & \multicolumn{2}{c}{ Activity } \\
\cline { 5 - 6 } Cells & $\begin{array}{c}2-\mathrm{ME} \\
\text { in buffer }\end{array}$ & $\begin{array}{c}\text { [DTT] } \\
\text { in assay }\end{array}$ & PCMB & $\begin{array}{c}\text { Lysyl } \\
\text { hydroxylase }\end{array}$ & $\begin{array}{c}\text { Prolyl } \\
\text { hydroxylase }\end{array}$ \\
\hline \multirow{3}{*}{ Mutant 2 } & $m M$ & $m M$ & & \multicolumn{2}{c}{$d p m \times 10^{-6 / 10^{8}}$ cells/h } \\
& 0 & 0 & 0 & 0.06 & 1.88 \\
& 0 & 0.1 & 0 & 0.13 & 15.9 \\
& 0 & 0.1 & + & 0.07 & N.D. \\
Control 1 & 50 & 0 & 0 & 0.24 & 9.90 \\
& 50 & 0.1 & 0 & 0.29 & 11.5 \\
& 0 & 0 & 0 & 0.21 & 0.38 \\
& 0 & 0.1 & 0 & 4.47 & 14.8 \\
& 0 & 0.1 & + & 0.14 & N.D. \\
& 50 & 0 & 0 & 4.29 & 10.1 \\
& 50 & 0.1 & 0 & 4.65 & 9.7 \\
\hline
\end{tabular}

Cell lysates were diluted 10-fold with $40 \mathrm{mM}$ Tris- $\mathrm{HCl}$ (pH 7.4), $250 \mathrm{mM}$ sucrose with or without $50 \mathrm{mM} 2-\mathrm{ME}$, and dialyzed at $4^{\circ} \mathrm{C}$ for $72 \mathrm{~h}$ against the same buffer. In some experiments PCMB (final concentration, $0.1 \mathrm{mM}$ ) was added to enzyme in assay solution containing cofactors but not DTT or protocollagen substrate. The assay was initiated by addition of the latter two ingredients immediately after PCMB was added.

$\alpha$-ketoglutarate, and ferrous sulfate). The inhibition by PCMB was still apparent even though DTT (to 100 $\mu \mathrm{M}$ ) was added at the time of assay.

When fibroblast lysates were dialyzed for $24 \mathrm{~h}$ at $4^{\circ} \mathrm{C}$ against buffer containing a relatively high concentration of DTT $(10 \mathrm{mM})$, the activities of prolyl hydroxylases from normal or mutant cells and the lysyl hydroxylase from normal cells were usually unaffected, but the activity of lysyl hydroxylase from mutant cells was invariably significantly enhanced (Table III). In other experiments performed under the same conditions, the activity of the mutant enzyme was less dramatically stimulated (twofold increase in activity compared to fourfold observed in some experiments). After prolonged dialysis versus buffers containing $10 \mathrm{mM}$ DTT $\left(48 \mathrm{~h}\right.$ or more at $4^{\circ} \mathrm{C}$ ) both normal and mutant lysyl hydroxylases lost considerable activity ( $50 \%$ or more).

When lysates containing $10 \mathrm{mM}$ DTT were added to the assay mixture, the resultant DTT concentration was higher than $100 \mu \mathrm{M}$. If the dialysis step was eliminated and the DTT concentration in the assay mixture was increased from 0.1 to $1 \mathrm{mM}$, the rate of collagen hydroxylation by the mutant lysyl hydroxylase was increased while prolyl hydroxylase activity was either slightly increased or decreased. The activity of the mutant enzyme was always higher when assayed in $1 \mathrm{mM}$ DTT, though the stimulation of activity often varied between experiments $(+20-+200 \%)$. The activity of normal lysyl hydroxylase was usually unaffected or slightly enhanced by $1 \mathrm{mM}$ DTT, although occasionally as much as $50 \%$ loss in activity was noted (Table IV). Studies of enzyme activity in varying concentrations of DTT (to $10 \mathrm{mM}$ ) indicated that the mutant lysyl hy-

TABLE III

Lysyl Hydroxylase Activities after Dialysis

\begin{tabular}{|c|c|c|c|}
\hline Cells & Buffer & $\begin{array}{l}\text { [DTT] } \\
\text { in assay }\end{array}$ & $\begin{array}{c}\text { Activity } \\
\text { lysyl } \\
\text { hydroxylase }\end{array}$ \\
\hline & & $m M$ & $\begin{array}{c}d p m \times 10^{-5} / \\
10^{8} \text { cells } / \mathrm{h}\end{array}$ \\
\hline \multirow[t]{4}{*}{ Mutant 1} & $\begin{array}{l}50 \mathrm{mM} \text { Tris-HCl } \\
(\mathrm{pH} 7.4) \\
10 \% \text { glycerol }\end{array}$ & 0.1 & 1.83 \\
\hline & $\begin{array}{l}50 \mathrm{mM} \text { Tris- } \mathrm{HCl} \\
150 \mathrm{~m} \mathrm{M} \mathrm{NaCl}\end{array}$ & 0.1 & 1.68 \\
\hline & $\begin{array}{l}50 \mathrm{mM} \text { Tris- } \mathrm{HCl} \\
10 \% \text { Glycerol } \\
10 \mathrm{mM} \text { DTT }\end{array}$ & 2.0 & 6.40 \\
\hline & $\begin{array}{l}50 \mathrm{mM} \text { Tris-HCl } \\
150 \mathrm{mM} \mathrm{NaCl} \\
10 \mathrm{mM} \text { DTT }\end{array}$ & 2.0 & 5.07 \\
\hline \multirow[t]{4}{*}{ Control } & $\begin{array}{l}50 \mathrm{mM} \text { Tris- } \mathrm{HCl} \\
10 \% \text { glycerol }\end{array}$ & 0.1 & 7.49 \\
\hline & $\begin{array}{l}50 \mathrm{mM} \text { Tris- } \mathrm{HCl} \\
150 \mathrm{~m} \mathrm{M} \mathrm{NaCl}\end{array}$ & 0.1 & 8.09 \\
\hline & $\begin{array}{l}50 \mathrm{mM} \text { Tris- } \mathrm{HCl} \\
10 \% \text { glycerol } \\
10 \mathrm{mM} \text { DTT }\end{array}$ & 2.0 & 7.07 \\
\hline & $\begin{array}{l}50 \mathrm{mM} \text { Tris- } \mathrm{HCl} \\
150 \mathrm{mM} \mathrm{NaCl} \\
10 \mathrm{mM} \text { DTT }\end{array}$ & 2.0 & 6.74 \\
\hline
\end{tabular}

Lysates from $10^{7}$ cells were diluted 10 -fold in the indicated buffers and then dialyzed overnight against the same buffer, and $0.2 \mathrm{ml}$ of the dialyzed enzyme solution was assayed. 
TABLE IV

Ascorbate and DTT and Activity of Hydroxylases

\begin{tabular}{|c|c|c|c|c|}
\hline \multirow[b]{2}{*}{ Cells } & \multirow[b]{2}{*}{ [DTT $]$} & \multirow[b]{2}{*}{ [Ascorbate] } & \multicolumn{2}{|c|}{ Hydroxylase activity } \\
\hline & & & Lysyl & Prolyl \\
\hline & $m M$ & $m M$ & $\begin{array}{c}d p m \times 10^{-5} / \\
10^{8} \text { cells }\end{array}$ & $\begin{array}{c}\mathrm{dpm} \times 10^{-6} / \\
10^{8} \mathrm{cells}\end{array}$ \\
\hline \multicolumn{5}{|c|}{ Experiment I } \\
\hline \multirow[t]{8}{*}{ Mutant 1} & 0.1 & 0.5 & 0.27 & 7.12 \\
\hline & 0.1 & 0 & 0.03 & 0.57 \\
\hline & 1 & 0.5 & 0.39 & 8.59 \\
\hline & 1 & 0 & 0.16 & 3.58 \\
\hline & 5 & 0.5 & 0.31 & 7.07 \\
\hline & 5 & 0 & 0.28 & 5.81 \\
\hline & 10 & 0.5 & 0.26 & 5.33 \\
\hline & 10 & $\mathbf{0}$ & 0.19 & 4.39 \\
\hline \multirow[t]{8}{*}{ Control } & 0.1 & 0.5 & 1.65 & 8.24 \\
\hline & 0.1 & $\mathbf{0}$ & 0.17 & 1.43 \\
\hline & 1 & 0.5 & 0.71 & 10.4 \\
\hline & 1 & 0 & 0.30 & 3.41 \\
\hline & 5 & 0.5 & 0.50 & 7.55 \\
\hline & 5 & $\mathbf{0}$ & 0.41 & 5.57 \\
\hline & 10 & 0.5 & 0.27 & 5.35 \\
\hline & 10 & 0 & 0.24 & 5.05 \\
\hline \multicolumn{5}{|c|}{ Experiment II } \\
\hline \multirow[t]{2}{*}{ Mutant 2} & 0.1 & 0.5 & 0.58 & 2.83 \\
\hline & 1.0 & 0.5 & 1.35 & 3.13 \\
\hline \multirow[t]{2}{*}{ Control } & 0.1 & 0.5 & 1.56 & 2.89 \\
\hline & 1.0 & 0.5 & 1.85 & 3.22 \\
\hline
\end{tabular}

droxylase was most active in the presence of $500 \mu \mathrm{M}$ ascorbate and $1 \mathrm{mM}$ DTT. Prolyl and lysyl hydroxylases from normal and mutant cells exhibited little or no activity when assayed in $0.1 \mathrm{mM}$ DTT without added ascorbate. However, with 1-10 mM DTT these enzymes could function in the absence of ascorbate (though suboptimally), presumably by utilizing DTT as an alternative reducing agent.

In an effort to determine if DTT-induced stimulation of mutant lysyl hydroxylase activity could be achieved in vivo, cell cultures were incubated in medium containing $10 \mathrm{mM}$ DTT for $1 \mathrm{~h}$. This treatment did not increase lysyl hydroxylase activity; rather prolyl and lysyl hydroxylase activities in normal and mutant cells were decreased $30-35 \%$.

\section{Cofactor and cosubstrate requirements}

Ascorbate. Measurements of the apparent $K_{m}$ for ascorbate revealed a discernible difference between wild-type and mutant lysyl hydroxylases (Fig. 3A and C). The enzyme in mutant cells had an apparent $K_{m}$ for this cofactor $(20 \mu \mathrm{M})$ approximately five times that of the normal enzyme $(4 \mu \mathrm{M})$. The ascorbate concentration routinely present in assay mixtures $(0.5 \mathrm{mM})$ was approximately 25 times the apparent $K_{m}$ of the mutant enzyme. Higher ascorbate concentrations (to $2.5 \mathrm{mM}$ ) did not increase enzyme activity. The DTT concentration affected the apparent $K_{m}$ of mutant enzyme for ascorbate. In the presence of $1 \mathrm{mM}$ DTT, the mutant enzyme exhibited a greater affinity for ascorbate (apparent $K_{m} 5 \mu \mathrm{M}$ ) (Fig. 3B), while the apparent $K_{m}$ of the normal enzyme was the same in 0.1 or $1.0 \mathrm{mM}$ DTT.

As compared with ascorbate, dehydroascorbate supported near maximal lysyl hydroxylation but only minimal prolyl hydroxylation (10\%) by enzymes from normal cells (Table V). However, with dehydroascorbate the rate of collagen lysyl hydroxylation by mutant enzyme was only $50-60 \%$ of the rate with ascorbate. Increasing the dehydroascorbate concentration from 0.5 $\mathrm{mM}$ to as high as $2.5 \mathrm{mM}$ did not increase the rate of lysyl hydroxylation by either normal or mutant enzymes. When DTT $(100 \mu \mathrm{M})$ was omitted from the assay mix-

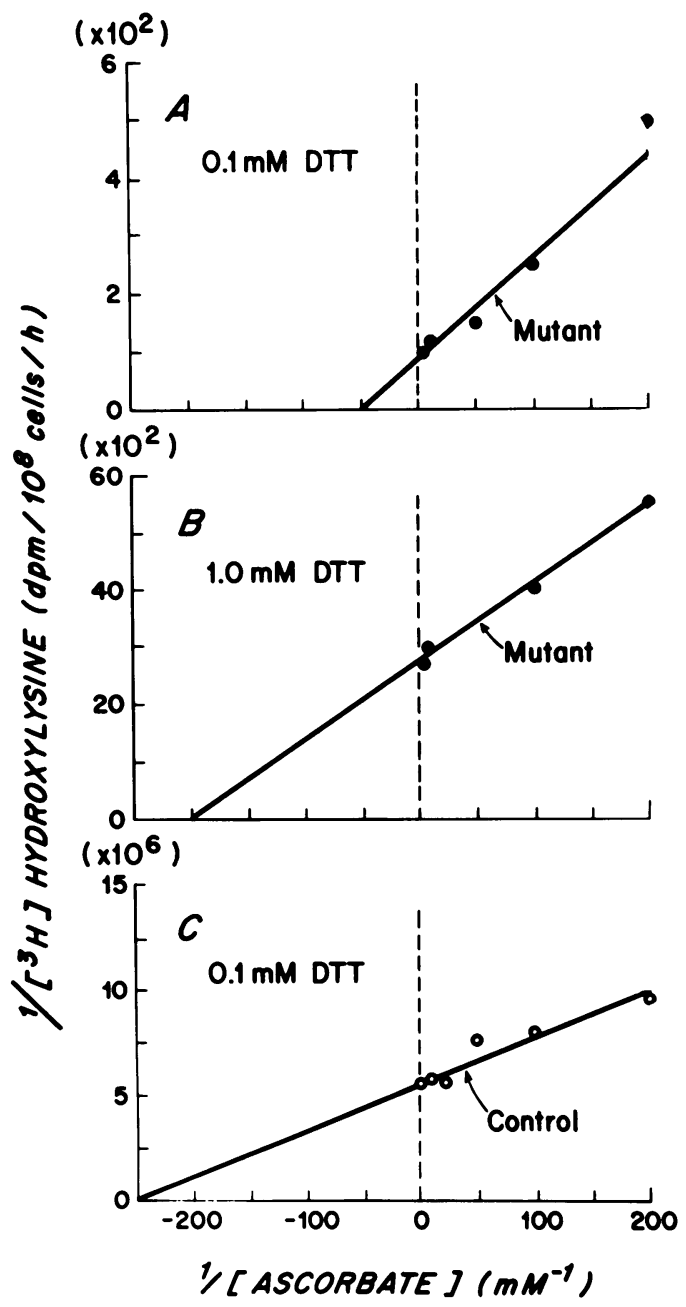

FIGURE 3 Double reciprocal plot of initial rate of collagen lysyl hydroxylation and ascorbate concentration. (A) Mutant enzyme assayed in $0.1 \mathrm{mM}$ DTT. (B) Mutant enzyme assayed in $1.0 \mathrm{mM}$ DTT. (C) Control enzyme assayed in $0.1 \mathrm{mM}$ DTT. 
TABLE V

Effect of Ascorbate, Dehydroascorbate, and Iron on Activities of Collagen Hydroxylases

\begin{tabular}{|c|c|c|c|c|c|c|}
\hline \multirow[b]{2}{*}{ Cells } & \multirow[b]{2}{*}{$\mathrm{Fe}(\mathrm{II})$} & \multirow[b]{2}{*}{$\mathrm{Fe}(\mathrm{III})$} & \multirow[b]{2}{*}{ (Ascorbate) } & \multirow{2}{*}{$\begin{array}{l}\text { (Dehydro- } \\
\text { ascorbate) }\end{array}$} & \multicolumn{2}{|c|}{ Hydroxylase activity } \\
\hline & & & & & Lysyl & Prolyl \\
\hline & $m M$ & $m M$ & $m M$ & $m M$ & \multicolumn{2}{|c|}{$d p m \times 10^{-6} / 10^{\circ}$ cells $/ h$} \\
\hline \multirow[t]{5}{*}{ Mutant 2} & 0.1 & 0 & 0.5 & 0 & 0.127 & 0.926 \\
\hline & 0 & 0 & 0.5 & 0 & 0.075 & 0.842 \\
\hline & 0 & 0.1 & 0.5 & 0 & 0.104 & 1.15 \\
\hline & 0.1 & 0 & 0 & 0.5 & 0.068 & 0.199 \\
\hline & 0 & 0.1 & 0 & 0.5 & 0.077 & 0.107 \\
\hline \multirow[t]{6}{*}{ Control } & 0.1 & 0 & 0.5 & 0 & 0.337 & 1.37 \\
\hline & 0 & 0 & 0.5 & 0 & 0.277 & 0.968 \\
\hline & 0 & 0.1 & 0.5 & 0 & 0.319 & 1.29 \\
\hline & 0.1 & 0.1 & 0.5 & 0 & 0.331 & 1.29 \\
\hline & 0.1 & 0 & 0 & 0.5 & 0.284 & 0.095 \\
\hline & 0 & 0.1 & $\mathbf{0}$ & 0.5 & 0.332 & 0.081 \\
\hline
\end{tabular}

ture, both wild-type and mutant enzymes exhibited little activity with dehydroascorbate. Colorimetric assay indicated no detectable ascorbate in dehydroascorbic acid ( $500 \mu \mathrm{M}$ in $40 \mathrm{mM}$ Tris- $\mathrm{HCl}, \mathrm{pH}$ 7.2) but when DTT was added to the solution (to $100 \mu \mathrm{M}$ ), the ascorbate concentration rose to $10 \mu \mathrm{g} / \mathrm{ml}$ (approximately $60 \mu \mathrm{M}$ ). Thus it appeared that prolyl hydroxylase might have a considerably higher apparent $K_{m}$ for ascorbate than either normal or mutant lysyl hydroxylase. Measurement of the apparent $K_{m}$ of prolyl hydroxylase for ascorbate $(100 \mu \mathrm{M})$ confirmed this prediction (Fig. 4).

$\alpha$-Ketoglutarate. Lysyl and prolyl hydroxylases from normal and mutant cells required $\alpha$-ketoglutarate in the assay solutions for the hydroxylation reactions to occur at significant rates. The lysyl hydroxylases in wild-type and mutant cells had similar affinities for $\alpha$-ketoglutarate (apparent $K_{m} 20 \mu \mathrm{M}$ ) (Fig. 5A and B). The apparent $K_{m}$ of prolyl hydroxylases from wild-type and mutant cells was $4 \mu \mathrm{M}$, and the Lineweaver-Burk plot indicates substrate inhibition of prolyl hydroxylase at $\alpha$-ketoglutarate concentrations above $100 \mu \mathrm{M}$ (Fig. 6). Though the activities of prolyl and lysyl hydroxylases were coordinately inhibited (70-96\%) by $5 \mathrm{mM} \alpha$-ketoglutarate, with $1 \mathrm{mM} \alpha$-ketoglutarate prolyl hydroxylase activity was selectively inhibited $80-90 \%$, while lysyl hydroxylase activity was affected only slightly.

Iron. Although crude cell lysates of normal and mutant fibroblasts required ferrous ion in assay solutions for collagen hydroxylations to occur at maximal rates, in the absence of this cofactor considerable activity was still observed (Table V). Ferric chloride did not inhibit either lysyl or prolyl hydroxylase and enzyme activities were about the same in either ferric chloride $(100 \mu \mathrm{M})$ or ferrous sulfate $(100 \mu \mathrm{M})$. Reduction of $\mathrm{Fe}$ (III) to
$\mathrm{Fe}$ (II) by ascorbate or DTT could be responsible for the observed effects.

Other properties of normal and mutant enzymes

Aggregation in low ionic strength buffers. The ionic strength of the extracting buffer had little effect on the solubility of lysyl hydroxylases in the $50,000 \mathrm{~g}$ supernate of cell lysates (see above), but molecular sieve chromatography indicated that the lysyl hydroxylase from normal cells formed high molecular weight aggregates in low ionic strength buffers. Lysyl hydroxylase activity was readily separable from prolyl hydroxylase activity when normal cell lysates (prepared in $40 \mathrm{mM}$ Tris- $\mathrm{HCl}, 250 \mathrm{mM}$ sucrose, $50 \mathrm{mM} 2-\mathrm{ME}$ with or without $0.1 \%$ Triton $\mathrm{X}-100$ ) were chromatographed on a

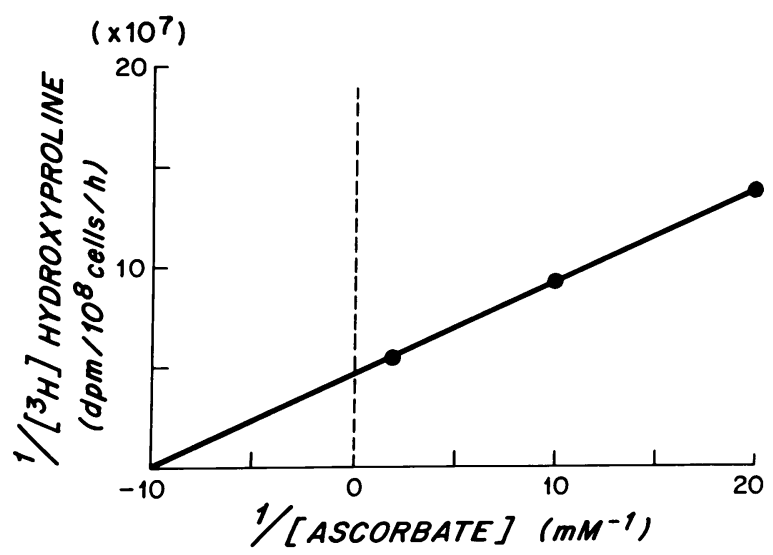

FIgURE 4 Double reciprocal plots of initial rate of collagen prolyl hydroxylation and ascorbate concentration. The data shown are those obtained with enzyme from wild-type cells, but an identical apparent $K_{m}$ was measured for enzyme in mutant cells. 


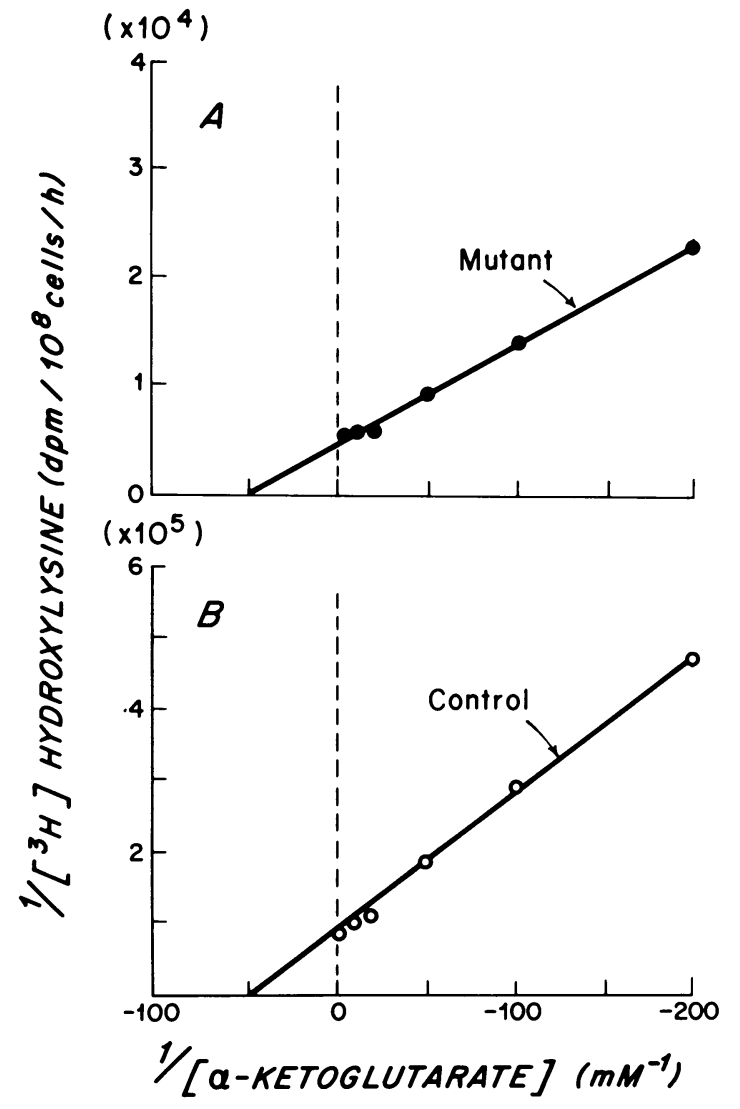

Figure 5 Double reciprocal plots of $\alpha$-ketoglutarate concentration and initial rate of collagen lysyl hydroxylation by enzymes in mutant (A) and control cells (B).

Bio-Gel A-1.5 column equilibrated and eluted with 50

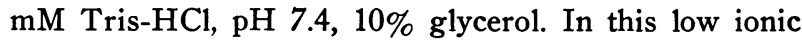
strength buffer, lysyl hydroxylase activity in normal cells was eluted in the region of the excluded volume, but this activity in mutant cells was present almost exclusively

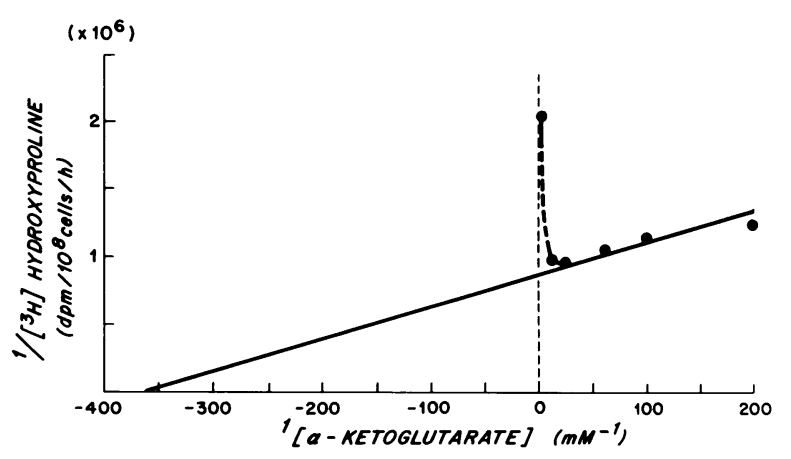

FIGURE 6 Double reciprocal plot of initial rate of collagen prolyl hydroxylation and $\alpha$-ketoglutarate concentration. The data shown are obtained from studies of the enzyme in mutant cells, but the enzyme in control cells gave identical results.

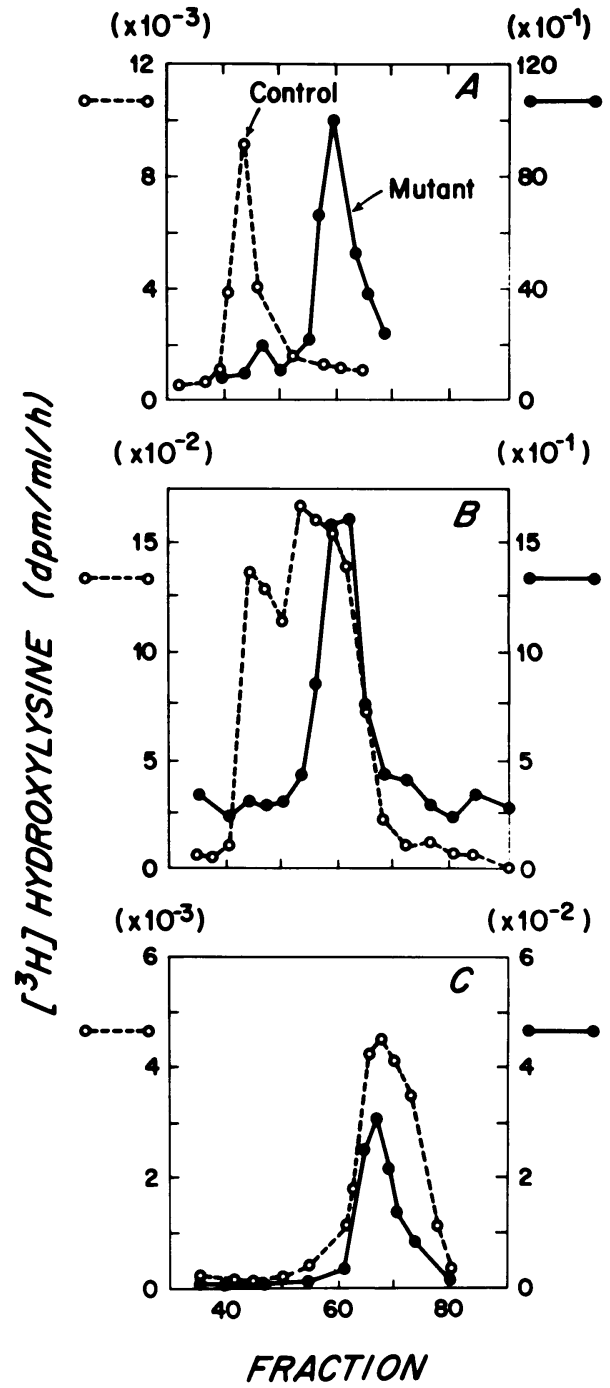

FIGURE $7 \mathrm{Gel}$ chromatography of lysyl hydroxylases in control and mutant cells. Bio-Gel A-1.5 column, $1.5 \times 81$ $\mathrm{cm}, 1.2 \mathrm{ml}$ fractions collected. (A) Buffer was $50 \mathrm{mM}$ Tris$\mathrm{HCl}, \mathrm{pH} 7.4,10 \%$ glycerol. (B) Buffer was $100 \mathrm{mM}$ Tris$\mathrm{HCl}, \mathrm{pH}$ 7.2, $50 \mathrm{mM}$ 2-ME. (C) Buffer was $50 \mathrm{mM}$ Tris- $\mathrm{HCl}, \mathrm{pH} 7.4,10 \%$ glycerol, $150 \mathrm{mM} \mathrm{NaCl}$.

in fractions corresponding to a lower molecular weight (Fig. 7A). Peak prolyl hydroxylase activity from both normal and mutant cells was eluted in fraction 60. Catalase (used to calibrate the column) was eluted in fractions 68-75. Lysyl hydroxylase activity in control cell lysates chromatographed in higher ionic strength buffer $(100 \mu \mathrm{M}$ Tris- $\mathrm{HCl}, \mathrm{pH} 7.2,50 \mathrm{mM} 2-\mathrm{ME})$ was eluted as two distinct but overlapping peaks, one in the region of high molecular weight aggregates excluded from the gel and the other in fractions preceding those containing prolyl hydroxylase activity. In $50 \mathrm{mM}$ Tris- $\mathrm{HCl}, 10 \%$ glycerol, $150 \mathrm{mM} \mathrm{NaCl}$, lysyl hydroxylase activity in 
TABLE VI

Effect of Incubation Temperature on Activity of Collagen Hydroxylases

\begin{tabular}{|c|c|c|c|c|c|}
\hline \multirow[b]{2}{*}{ Cells } & \multirow[b]{2}{*}{ Temperature } & \multicolumn{4}{|c|}{ Hydroxylase activity } \\
\hline & & Lysyl & $\begin{array}{c}\text { Maximal } \\
\text { activity }\end{array}$ & Prolyl & $\begin{array}{l}\text { Maximal } \\
\text { activity }\end{array}$ \\
\hline & ${ }^{\circ} \mathrm{C}$ & $d p m \underset{c e l l s / h}{\times 10^{-s} / 10 s}$ & $\%$ & $d_{\text {cells } / h} \times 10^{-5} / 10^{s}$ & $\%$ \\
\hline \multirow[t]{7}{*}{ Mutant 1} & 20 & 0.189 & 69 & 0.699 & 28 \\
\hline & 25 & 0.258 & 94 & 1.02 & 41 \\
\hline & 30 & 0.273 & 100 & 1.87 & 76 \\
\hline & 34 & 0.168 & 61 & 2.21 & 89 \\
\hline & 37 & 0.087 & 32 & 2.48 & 100 \\
\hline & 40 & 0.066 & 24 & 2.20 & 89 \\
\hline & 45 & 0.010 & 4 & 1.51 & 61 \\
\hline \multirow[t]{7}{*}{ Control } & 20 & 0.453 & 34 & 0.395 & 26 \\
\hline & 25 & 0.950 & 71 & 0.592 & 39 \\
\hline & 30 & 1.28 & 97 & 1.24 & 83 \\
\hline & 34 & 1.30 & 100 & 1.41 & 95 \\
\hline & 37 & 1.14 & 88 & 1.49 & 100 \\
\hline & 40 & 0.980 & 74 & 1.37 & 91 \\
\hline & 45 & 0.472 & 20 & 0.99 & 66 \\
\hline
\end{tabular}

normal cells was eluted in fractions corresponding to a low molecular weight component. Aggregation of prolyl hydroxylase was not influenced by ionic strength since in every buffer prolyl hydroxylase activity was eluted in identical fractions.

Thermal stability. Lysyl hydroxylase activity in lysates of normal and deficient cells was diminished by approximately $95 \%$ after heating the enzyme (in solution with cofactors except for collagen substrate) $5 \mathrm{~min}$ at $60^{\circ} \mathrm{C}$. After $15 \mathrm{~min}$ at $50^{\circ} \mathrm{C}$, approximately $35 \%$ of the activity of the enzymes from both sources was retained. At lower temperatures the relative instability of the mutant enzyme was apparent. Though lysyl hydroxylase activity in lysates of normal cells was maximal when the assay mixtures were incubated at $34^{\circ} \mathrm{C}$ (for $60 \mathrm{~min}$ ), approximately the same activity was measured after incubation at $30^{\circ}, 34^{\circ}$, and $37^{\circ} \mathrm{C}$ (Table VI). Lysyl hydroxylase from mutant cells exhibited peak activity when incubation was at $30^{\circ} \mathrm{C}$, and incubation at $37^{\circ} \mathrm{C}$ resulted in a $68 \%$ decrease in the rate of collagen lysyl hydroxylation. Prolyl hydroxylase from both normal and mutant cells exhibited maximal activity when incubation was at $37^{\circ} \mathrm{C}$.

\section{DISCUSSION}

The finding that skin fibroblasts from siblings with hydroxylysine-deficient collagen (Ehlers-Danlos syndrome, type VI) contained much lower collagen lysyl hydroxylase activity than cells from normal subjects offered an experimental system amenable to further study of the nature of the defect. Diminished enzyme activity could conceivably be due to: (a) a normal enzyme in normal amount but in an environment where it is inactive (e.g. combined with another protein or attached to a membrane); (b) a normal or abnormal enzyme present in subnormal amount as a result of decreased synthesis, increased degradation, or defect in activation of a proenzyme; (c) a normal enzyme present in normal amount but less active due to the presence of inhibitors or absence of activators; $(d)$ an abnormal enzyme with altered kinetic properties. We have been able to provide some data regarding these possibilities. Our studies indicate that normal amounts of enzyme activity cannot be extracted from mutant cells. Diminished lysyl hydroxylase activity is evident in whole cell sonicates and in the $50,000 \mathrm{~g}$ supernates of mutant cell lysates in low or high ionic strength buffers or in buffer containing detergent. A small amount of lysyl hydroxylase activity is found in sedimentable fractions of cell sonicates and can be solubilized by extraction of acetone powders of these fractions; however, the activity in the mutant cells is proportionally reduced in each of these fractions.

Studies of collagen prolyl hydroxylase in L-929 mouse fibroblasts indicated that during early log phase of culture growth, ascorbate may play a role in activation of prolyl hydroxylase (9). We found prolyl hydroxylase activity was decreased in ascorbate-supplemented wildtype or mutant human fibroblast cultures, but since lysyl hydroxylase activity was unaffected, or slightly elevated, the net result was an increase in the ratio of lysyl hydroxylase activity to prolyl hydroxylase activity. Our data concerning the effect of ascorbate on hydroxylase 
activities in human skin fibroblasts cannot be directly compared with the studies of L-929 cells. We did not examine the effect on hydroxylase activities $1 \mathrm{~h}$ after administration of ascorbate to cultures in early log phase of growth; rather, we studied the effects of ascorbate supplementation throughout culture growth to confluence.

The results of studies of lysyl hydroxylase activity in mixtures of normal and mutant cell lysates indicate neither inhibition of enzyme in normal cells by material in mutant cells nor activation of enzyme in mutant cells by lysate of normal cells. A number of our observations suggest that the most probable reason for low lysyl hydroxylase activity in mutant cells is an alteration in the primary structure of the enzyme. Since all properties of lysyl hydroxylase from the two siblings were identical, we assume the same altered enzyme is present in skin fibroblasts from both individuals. The enzyme from deficient cells is less stable at $37^{\circ} \mathrm{C}$ than the normal enzyme. Mutant and wild-type enzymes show differences in aggregation properties : the wild type forms high molecular weight aggregates in low ionic strength buffers, but the mutant enzyme does not. In some experiments, after dialysis against buffer containing $10 \mathrm{mM}$ DTT, the activity of the mutant enzyme was stimulated to a level comparable to that of the normal enzyme. These data suggest that the defective enzyme protein is present in deficient cells, and although the mutant enzyme is relatively inactive under conditions where the normal enzyme is fully active, under certain conditions it can be activated. Although mutant and wild type lysyl hydroxylases have identical affinities for $\alpha$-ketoglutarate and exhibit a similar requirement for either $\mathrm{Fe}$ (II) or $\mathrm{Fe}$ (III), in the presence of $100 \mu \mathrm{M}$ DTT the mutant enzyme has an apparent $K_{m}$ for ascorbate approximately five times that of the normal enzyme. The concentration of DTT present in the assay solution ( 0.1 or $1.0 \mathrm{mM}$ ) had no effect on the apparent $K_{m}$ of the normal enzyme for ascorbate, but in $1 \mathrm{mM}$ DTT the apparent $K_{m}$ of the mutant enzyme approached that of the normal. However, since assays were performed with an ascorbate concentration well in excess of the apparent $K_{m}$ of the mutant enzyme, the stimulation of activity by DTT must have an additional explanation, which we cannot provide at this time. We also note that interpretation of all of our kinetic studies must take into account the use of underhydroxylated collagen substrate at less than saturating concentrations. However, since all of the apparent $K_{m}$ 's were determined from Lineweaver-Burk plots, which were linear, it is likely that the analyses are valid.

Hydroxylases in buffer without 2-ME are inactive unless DTT is present in the assay mixture. Furthermore, $\mathrm{PCMB}$ is inhibitory. It would thus appear, as in chick embryo enzymes $(11,18)$, that sulfhydryl groups are necessary for activity. However, lysyl and prolyl hydroxylases in crude lysates of wild-type or mutant human skin fibroblasts are relatively stable in high concentrations of sulfhydryl reagents $(10 \mathrm{mM}$ DTT or 50 $\mathrm{mM}$ 2-ME), although collagen hydroxylases from chick embryos are known to be inactivated by such concentrations of sulfhydryl compounds $(11,18)$. Although we found some loss of prolyl and lysyl hydroxylase activity in human cells incubated with $1 \mathrm{mM}$ DTT in the culture medium, incubation of L-929 cells with this concentration of DTT caused loss of activity interpreted as due to disaggregation of prolyl hydroxylase into inactive subunits (9). It would appear that collagen hydroxylases from different sources may have different characteristics.

As yet we have little information that would help to explain the variation in hydroxylysine content of collagens from different tissues of the two subjects studied here. The existence of multiple forms of lysyl hydroxylase in various tissues remains a possibility, although other explanations are also likely. Lysyl and prolyl hydroxylases cannot act upon their specific residues if the component collagen polypeptides are in triple helical conformation (19-21). Therefore additional factors controlling lysyl hydroxylation could involve the relative rate of prolyl hydroxylation, the rate of chain synthesis, association, and helix formation, and the intracellular sites where these reactions take place. Recent evidence suggests that the time of chain association can be different in different tissues. Chain association and helix formation in chick embryo cartilage cells apparently occur at a later stage than in chick embryo tendon cells; the lateness of chain association in cartilage cells could be one of the factors influencing the high hydroxylysine content of cartilage collagen (22).

Cofactor concentrations may also regulate the activities of collagen lysyl and prolyl hydroxylases and could therefore play a role in determining the extent to which lysine residues are hydroxylated, particularly if in some tissues these hydroxylations occur in different cellular compartments. Even though lysyl and prolyl residues are simultaneously hydroxylated in the same cellular location, the relative activities of the two enzymes would not necessarily be coupled. We found that $1 \mathrm{mM}$ $\alpha$-ketoglutarate almost completely inhibited prolyl hydroxylase, while lysyl hydroxylase activity was diminished only slightly. At low $\alpha$-ketoglutarate concentrations the opposite effect occurs, since prolyl hydroxylase has greater affinity for this cofactor. Ascorbate concentration could also regulate the relative activities of the two hydroxylases, since prolyl hydroxylase has a significantly lower affinity for ascorbate than either normal or mutant lysyl hydroxylase. The difference in apparent $K_{m}$ for ascorbate of prolyl and lysyl hydroxylases may be characteristic of enzymes from other sources, since 
it has been shown that ascorbate-deficient 3T6 mouse embryo cells synthesize collagen severely deficient in hydroxyproline but only moderately deficient in hydroxylysine (23).

The rate and sequence of events in collagen synthesis and cofactor concentrations and therefore the relative activities of prolyl and lysyl hydroxylases may vary from tissue to tissue. It is possible that all tissues of individuals with hydroxylysine-deficient collagen contain a mutant lysyl hydroxylase with altered kinetic properties, but the hydroxylysine content of the collagens synthesized by cells of different origin need not be reduced to the same extent. In this respect it would be important to determine if all subjects with the disorder show a similar reduction in the level of lysyl hydroxylation in collagens from different tissues. Though hydroxylysinedeficient skin collagen and low skin fibroblast lysyl hydroxylase activity has been established in another subject with Ehlers-Danlos syndrome type VI (24), information is not yet available concerning the hydroxylysine content of other tissues. Further studies of collagen hydroxylase activities may indicate the reasons for a variability in the hydroxylysine deficiency of these collagens. The decreased extent of hydroxylation must be critical in the alteration of mechanical properties of the collagen from different tissues, which must, in turn, be responsible for the abnormal phenotype.

\section{ACKNOWLEDGMENTS}

We thank Drs. R. W. Erbe and S. R. Pinnell for helpful discussions. We thank M. Byrne, M. Holland, S. Eagles, M. McGuire, and C. Rogers for technical assistance.

These studies were supported by U. S. Public Health Service grants AM-03564, AM-05067, and AM-04501. This is publication 680 of the Robert W. Lovett Memorial Group for the Study of Diseases Causing Deformities.

\section{REFERENCES}

1. Pinnell, S. R., S. M. Krane, J. E. Kenzora, and M. J. Glimcher. 1972. A heritable disorder of connective tissue. Hydroxylysine deficient collagen disease. N. Engl. J. Med. 286: 1013-1020.

2. Eyre, D. R., and M. J. Glimcher. 1972. Reducible crosslinks in hydroxylysine-deficient collagens of a heritable disorder of connective tissue. Proc. Natl. Acad. Sci. U.S. A. 69: 2594-2598.

3. Krane, S. M., S. R. Pinnell, and R. W. Erbe. 1972. Lysyl-protocollagen hydroxylase deficiency in fibroblasts from siblings with hydroxylysine-deficient collagen. Proc. Nat. Acad. Sci. U. S. A. 69: 2899-2903.

4. Takeuchi, T., and D. J. Prockop. 1969. Protocollagen proline hydroxylase in normal liver and in hepatic fibrosis. Gastroenterology. 56: 744-750.

5. Guzman, N. A., and K. R. Cutroneo. 1973. Association of prolyl hydroxylase activity with membranes. Biochem. Biophys. Res. Commun. 52: 1263-1270.

6. Rhoads, R. E., and S. Udenfriend. 1970. Purification and properties of collagen proline hydroxylase from newborn rat skin. Arch. Biochem. Biophys. 139: 329339.
7. Berg, R. A., and D. J. Prockop. 1973. Affinity column purification of protocollagen proline hydroxylase from chick embryos and further characterization of the enzyme. J. Biol. Chem. 248: 1175-1182.

8. McGee, J. O'D., U. Langness, and S. Udenfriend. 1971. Immunological evidence for an inactive precursor of collagen proline hydroxylase in cultured fibroblasts. Proc. Natl. Acad. Sci. U. S. A. 68: 1585-1589.

9. Stassen, F. L. H., G. J. Cardinale, and S. Udenfriend. 1973. Activation of prolyl hydroxylase in L-929 fibroblasts by ascorbic acid. Proc. Natl. Acad. Sci. U. S. A. 70: 1090-1093.

10. Popenoe, E. A., and R. B. Aronson. 1972. Partial purification and properties of collagen lysine hydroxylase from chick embryos. Biochim. Biophys. Acta. 258: 380386.

11. Kivirikko, K. I., and D. J. Prockop. 1972. Partial purification and characterization of protocollagen lysine hydroxylase from chick embryos. Biochim. Biophys. Acta. 258: 366-379.

12. Miller, R. L. 1971. Chromatographic separation of enzymes required for hydroxylation of lysine and proline residues of protocollagen. Arch. Biochem. Biophys. 147 : 339-342.

13. Morton, R. K. 1955. Methods of extraction of enzymes from animal tissues. Methods Enzymol. 1: 25-51.

14. Blumenkrantz, N., and D. J. Prockop. 1969. A rapid assay for ${ }^{14} \mathrm{C}$-labeled hydroxylysine in collagen and related materials. Anal. Biochem. 30: 377-385.

15. Klevecz, R. R., and F. H. Ruddle. 1968. Cyclic changes in enzyme activity in synchronized mammalian cell cultures. Science (Wash. D. C.). 159: 634-636.

16. Schmall, M., C. W. Pifer, and E. G. Wollish. 1953. Determination of ascorbic acid by a new colorimetric reaction. Anal. Chem. 25: 1486-1490.

17. Smith, J. A. 1972. An improved method of ascorbic acid measurement in the ovarian ascorbic acid depletion assay. J. Endocrinol. 55: 461-462.

18. Popenoe, E. A., R. B. Aronson, and D. D. Van Slyke. 1969. The sulfhydryl nature of collagen proline hydroxylase. Arch. Biochem. Biophys. 133: 286-292.

19. Rhoads, R. E., S. Udenfriend, and P. Bornstein. 1971. In vitro enzymatic hydroxylation of prolyl residues in the $\alpha 1-\mathrm{CB} 2$ fragment of rat collagen. J. Biol. Chem. 246: 4138-4142.

20. Murphy, L., and J. Rosenbloom. 1973. Evidence that chick tendon procollagen must be denatured to serve as substrate for proline hydroxylase. Biochem. J. 135 : 249251.

21. Kivirikko, K. I., L. Ryhänen, H. Anttinen, P. Bornstein, and D. J. Prockop. 1973. Further hydroxylation of lysyl residues in collagen by protocollagen lysyl hydroxylase in vitro. Biochemistry. 12: 4966-4971.

22. Uitto, J., and D. J. Prockop. 1974. Biosynthesis of cartilage procollagen. Influence of chain association and hydroxylation of prolyl residues on the folding of the polypeptides into triple-helical conformation. Biochemistry. 13 : 4586-4591.

23. Bates, C. J., C. J. Prynne, and C. I. Levene. 1972. Ascorbate-dependent differences in the hydroxylation of proline and lysine in collagen synthesized by 3T6 fibroblasts in culture. Biochim. Biophys. Acta. 278: 610-616.

24. Sussman, M., J. R. Lichtenstein, T. P. Nigra, G. R. Martin, and V. A. McKusick. 1974. Hydroxylysinedeficient skin collagen in a patient with a form of EhlersDanlos syndrome. J. Bone Jt. Surg. Am. Vol. 56A: 1228-1234. 